\title{
Hubungan Antara Self Regulation dengan Pengetahuan Mengenai Analisis Perkembangan Sosial pada Mahasiswa
}

\author{
Irene Prist*, Umi Nur Holifah** \\ UIN Raden Fatah Palembang \\ e-mail: ireneprist25@gmail.com*,umicahaya_uin@radenfatah.ac.id**
}

\begin{abstract}
Abstrak
Tujuan riset ini merupakan buat mengenali ikatan antara self- regulation dengan pengetahuan menimpa analisis pertumbuhan sosial pada mahasiswa fakultas psikologi UIN RF. Populasi dari riset ini merupakan mahasiswa fakultas psikologi semester 6. Ilustrasi dalam riset ini mahasiswa fakultas psikologi yang lagi mengampuh mata kuliah PARK (Pertumbuhan Anak serta Anak muda Berkebutuhan Spesial). Dimana ilustrasi pada riset ini berjumlah 30 mahasiswa. Buat mengukur pengetahuan memakai kuesioner yang dirancang oleh periset sendiri bersumber pada aspek- aspek pengetahuan yang dikemukakan oleh Notoadmodjo serta kuesioner selfregulation memakai kuesioner rancangan periset bersumber pada aspek- aspek self- regulation yang dikemukakan oleh Zimmerman serta Pons. Riset ini memakai pendekatan kuantitatif dengan memakai tata cara survei. Riset ini diucap tipe riset korelatif, sebab hendak mendapatkan data sejauhmana korelasi antara self- regulation dengan pengetahuan pada mahasiswa fakultas psikologi UIN RF. Metode analisis informasi yang digunakan dalam riset ini merupakan korelasi product moment dari Spearman. Uji normalitas informasi dicoba dengan uji Kolmogorov- Smirnov dengan memakai uji statistika. Dari hasil riset, hingga disimpulkan kalau ada korelasi positif yang signifikan antara self- regulation dengan pengetahuan menimpa analisis pertumbuhan sosial pada mahasiswa fakultas psikologi UINRF sebesar positif 0, 505 dengan taraf signifikansi sebesar $\mathrm{p}=$ 0, 004 dengan hasil uji normalitas dikenal nilai signifikansi 0, $246>0.05$ hingga bisa disimpulkan kalau nilai residual berdistribusi wajar.
\end{abstract}

Kata Kunci: Pengetahuan, self-regulation, mahasiswa

\begin{abstract}
The purpose of this research is to identify the relationship between self-regulation and knowledge over the analysis of social growth in psychology students of UIN RF. The population of this research is 6th semester psychology faculty students. The illustration in this research is psychology faculty students who are currently taking PARK (Child Growth and Young People with Special Needs) courses. Where the illustrations in this research are 30 students. To measure knowledge using a questionnaire designed by the researchers themselves based on aspects of knowledge proposed by Notoadmodjo and self-regulation questionnaires using a questionnaire designed by researchers based on aspects of self-regulation proposed by Zimmerman and Pons.
\end{abstract}


This research uses a quantitative approach by using a survey procedure. This research is called the type of correlative research, because it wants to get data on the extent of the correlation between self-regulation and knowledge of psychology students of UIN RF. Information analysis method used in this research is Spearman's product moment correlation. The information normality test was tested with the Kolmogorov-Smirnov test using statistical tests. From the results of the research, it was concluded that there was a significant positive correlation between self-regulation and knowledge overriding the analysis of social growth in psychology faculty students at UINRF which was positive 0.505 with a significance level of $p=0.004$ with the results of the normality test known as a significance value of 0,246>0.05 so it can be concluded that the residual value is fairly distributed.

Keywords: Knowledge, self-regulation, psychology faculty students

\section{PENDAHULUAN}

Pengetahuan di bidang pendidikan merupakan salah satu indikator keberhasilan dalam pembelajaran. Mahasiswa yang sangat melmiliki rasa keingin tahuan yang sangat tinggi akan memudahkan mahasiswa dalam meningkatkan pemahaman materi pembelajaran. Sehingga mampu mengoptimalkan aspek perkembangan mahasiswa dalam belajar. Mahasiswa ialah sebuah individu yang belajar disebuah perguruan tinggi, dimana telah mampu belajar secara mandiri sebab telah mempunyai kedudukan tertinggi dan usia yang telah dewasa. Menurut Sarwono (Gafur, 2015) mahasiswa merupakan individu yang sudah secara resmi terdaftar untuk melaksanakan pembelajaran di perguruan tinggi dengan kisaran usia 18-30 tahun.

Upaya yang dicoba di bidang pembelajaran dalam mengusahakan tercapainya pembelajaran tersebut dicoba dengan memfasilitasi pertumbuhan mahasiswa yang hendak jadi pembelajar sejauh masa. Buat jadi pembelajar sejauh masa, mahasiswa diharapkan mempunyai keahlian dasar buat belajar yang hendak digunakannya dalam bermacam konteks di waktu- waktu mendatang. Sistem pembelajaran di masa saat ini ini, mewajibkan mahasiswa buat belajar secara mandiri guna

menaikkan pengetahuan dan uraian menimpa modul pendidikan.

Pengetahuan di miliki dari hasil“" ketahui" sehabis melaksanakan pengindraan terhadap sesuatu objek tertentu. Proses pengindraan bisa terjalin lewat panca indera manusia ialah

indera penglihatan, penciuman, raba, rungu, serta rasa. Kebanyakan pengetahuan manusia didapatkan lewat mata serta kuping. Namun terdapat pula yang lewat sesuatu proses ialah proses belajar yang memerlukan sesuatu dorongan, misalnya dorongan seorang yang lebih memahami suatu perihal, dorongan perlengkapan misalnya novel serta sebagainya. Sikap yang didasari pengetahuan biasanya besifat langgeng( bertahan lama).

Pengetahuan yang dicakup memiliki 6 tingkatan(Sunaryo, 2004) ialah: Awal merupakan ketahui, yang maksudnya bisa mengingat kembali sesuatu perihal yang sempat dipelajari tadinya. Kedua, menguasai yang mempunyai makna keahlian buat menarangkan serta menginterpretasikan dengan benar tentang objek yang dikenal. Ketiga, aplikasi ataupun pelaksanaan ialah 
keahlian buat memakai modul yang sudah dipelajari pada suasana serta keadaan yang nyata. Keempat, analisis ialah keahlian buat menguraikan objek kedalam bagian- bagian lebih kecil serta masih terpaut satu sama lain. Kelima, sintesis, ialah keahlian buat menghubungkan bagian- bagian didalam sesuatu wujud totalitas yang baru. Keenam, penilaian ialah keahlian buat melaksanakan evaluasi terhadap sesuatu objek.

Kemandirian belajar ini biasa pula diucap dengan self- regulation ataupun regulated learning. Self regulated learning diperlukan mahasiswa dalam aktivitas belajar supaya mahasiswa memiliki keahlian dalam mengendalikan serta memusatkan dirinya dalam belajar, membiasakan serta mengatur diri, paling utama dalam mengalami tugas yang belum dimengerti. Mahasiswa dituntut sanggup mengendalikan diri dalam belajar. Mahasiswa wajib sanggup merancang aktivitas belajarnya dengan maksimal, sanggup memanjemen waktu sehingga agenda belajar dicoba dengan tertib, mahasiswa mengenali metode menghasilkan area belajar yang baik serta mengasyikkan dalam tipe dirinya, mahasiswa disiplin belajar dengan mandiri, mahasiswa pula memiliki perencanaan buat menggapai tujuan, sanggup menggunakan sarana yang terdapat, serta tidak menunda dalam mengerjakan tugas.

Bagi (Zimmerman, 1989) mengatakan kalau pengelolaan diri ataupun self- regulation mempunyai 3 aspek yang diterapkan dalam belajar (Ghufron, 2012), ialah: Awal, metakognitif ialah uraian serta pemahaman menimpa proses kognitif ataupun benak. Kedua, motivasi ialah sesuatu guna dari kebutuhan dasar buat mengendalikan serta berkaitan dengan keahlian yang terdapat pada masing- masing orang. Ketiga, sikap ialah upaya orang dalam mengendalikan diri, menyeleksi, serta menggunakan maupun menciptkan area yang menunjang kegiatannya (Ghufron, 2012).

Zimmerman serta Pons mengatakan pula kalau terdapat sebagian aspek yang pengaruhi pengelolaan diri ataupun seldregulation(Ghufron, 2012) ialah antara lain:

1. Individu ( diri)

a. Pengetahuan orang. Terus menjadi banyak serta bermacam- macam pengetahuan orang hingga hendak menolong orang dalam melaksanakan pengelolaan.

b. Tingkatan keahlian metakognisi yang dipunyai orang yang kian besar hendak menolong penerapan pengelolaan diri orang.

c. Tujuan yang mau dicapai, terus menjadi banyak tujuan yang mau diraih terus menjadi besar mungkin inidividu melaksanakan pengelolaan diri.

2. Perilaku

Bandura (Ghufron, 2012) menyatakan bahwa dalam hal ini ada 3 sesi yang berkaitan dengan pengelolaan diri yaitu antara lain:

a. Selfabservation

Berkaitan dengan respon seseorang

b. Self judgment

Sesi orang menyamakan performansi serta standar yang telah dikerjakannya dengan tujuan yang telah diresmikan.

c. Self reaction

Sesi mencakup proses orang dalam membiasakan diri serta rencana buat 
menggapai tujuan ataupun standar yang ditetapkan (Ghufron, 2012).

\section{Lingkungan}

Teori sosial kognitif membagikan atensi spesial pada pengaruh sosial serta pengalaman pada guna manusia. perihal ini tergantung pada area yang menunjang ataupun tidak(Ghufron, 2012).

Bersumber pada faktor- faktor diatas bisa disimpulkan kalau yang pengaruhi pengelolaan diri merupakan personal, sikap serta lingkungan. Semuanya berkaitan satu sama lainnya.

Pembelajaran secara daring dapat menjadikan mahasiswa menerapkan kemandirian mahasiswa dalam belajar salah satunya adalah dengan cara mencari materi perkuliahan serta kreativitas dalam mengerjakan tugas. Namun fenomena yang terjadi dalam lapangan merupakan belum tahunya mahasiswa melakukan self regulated learning dengan sangat baik. Dimana mahasiswa mengalami kesulitan dalam mengatasi problematika pembelajaran dalam materi perkembangan sosial pada ABK (Anak Berkebutuhan Khusus) seperti mahasiswa hanya menunggu penyampaian materi dari dosen saja, sehingga pemahaman akan pembelajaran masih kurang efektif, mahasiswa sulit menggunakan waktu dengan efisien belajar secara daring.

Masih ada beberapa mahasiswa yang enunda pekerjaan atau tugas yang diberikan oleh dosen, Mahasiswa harus bias untuk membagi waktu untuk mengerjakan pekerjaan rumah dengan tugas kuliah, sulit membuat rencana dalam mencapai pencapaian belajar yang baik, kurang menggunakan fasilitas dengan baik seperti internet, handphone dan sebagainya. Hal ini dapat dipengaruhi oleh lemahnya salah satu atau bahkan lebih dari faktor self regulated learning. Dalam pembelajaran daring mahasiswa baru mesti mempunyai kemampuan mempengaruhi pengetahuan yang dimilikinya serta menetapkan tujuan sebagai hasil proses berpikir dan belajarnya, dan afeksi sebagai emosi yang dimiliki.

Pertanyaan yang akan menjadi fokus masalah dalam penelitian ini adalag apakah terdapat hubungan antara self-regulation dengan pengetahuan mengenai analisis perkembangan sosial pada mahasiswa fakultas psikologi UIN RF, yang aktif dan mengampuh mata kuliah PARK?

Oleh sebab itu penulis mau mengangkut suatu topik dengan bahasan gimana korelasi self- regulation dengan pengetahuan menimpa analisis pertumbuhan sosial sehingga hendak didapatkan hasil yang bermanfaat selaku rujukan mahasiswa, guru, dosen, ataupun tenaga pendidik yang lain guna tercapainya tujuan pendidikan dalam pembelajaran.

\section{Pengetahuan}

2009) kalau pengetahuan ialah suatu kepercayaan hendak kebenaran yang terjustifikasi. Pengetahuan ialah sumber energi yang tidak nampak serta terletak di otak tiap- tiap orang, yang ialah sesuatu kepercayaan hendak kebenaran yang terjustifikasi yang bisa bertambah kapasitas dalam aksi yang efisien.

Bagi Notoadmodjo(Rajaratenam et al., 2014) pengetahuan ialah khasanah kekayaan mental secara langsung ataupun tidak langsung ikut memperkaya kehidupan kita. 
Bagi Notoadmodjo, tiap pengetahuan memiliki identitas yang khusus menimpa apa( ontologi) gimana( epistologi) serta buat apa( aksiologi). Pengetahuan yang dipunyai seorang pengaruhi prilakunya, terus menjadi baik pengetahuan seorang hingga prilakunya juga terus menjadi baik(Rajaratenam et al., 2014).

Pengetahuan di miliki dari hasil“" ketahui" sehabis melaksanakan pengindraan terhadap sesuatu objek tertentu. Pengindraan terjalin lewat kelima pancaindra manusia, ialah: indra penglihatan, rungu, penciuman, rasa, serta raba. Bagi Notoadmodjo, sebagian besar pengetahuan manusia diperoleh lewat mata serta kuping. Namun sebagian besar memalui siatu proses ialah proses belajar serta memerlukan sesuatu dorongan, misalnya dorongan seseoroang yang lebih memahami suatu perihal, dorongan perlengkapan misalnya novel serta sebagainya(Saadah et al., 2020).

Bagi (Notoatmodjo \& Soekidjo, 2003), pengetahuan ialah hasil dari ketahui yang terjalin lewat proses sensoris ialah mata serta kuping terhadap objek tertentu. Dalam membentuk sesuatu sikap terbuka, pengetahuan jadi domain yang berarti. Dimana pengetahuan ataupun aksi kognitif jadi salah satu aspek dalam terjadinya aksi seorang. Sikap yang didasari pengetahuan biasanya besifat langgeng( bertahan lama). Pengetahuan yang dicakup memiliki 6 tingkatan ialah(Sunaryo, 2004):

$\begin{array}{crrr}1 . & \text { Ketahui, } & \text { ialah } & \text { tingkatan } \\ \text { pengetahuan } & \text { sangat } & \text { rendah. } & \text { Ketahui }\end{array}$ maksudnya bisa mengingat ataupun mengingat kembali sesuatu yang perihal yang sempat dipelajari tadinya. Dimensi seorang itu dikatakan ketahui, merupakan kala dia bisa mengatakan, menguraikan, mendefinisikan, serta melaporkan.
2. Menguasai, ialah keahlian buat menarangkan serta menginterpretasikan dengan benar tentang objek yang dikenal. Kala seorang sudah mengerti menimpa suatu hingga wajib bisa membagikan contoh, menarangkan dan merumuskan.

3. Aplikasi ataupun pelaksanaan, ialah keahlian buat memakai modul yang sudah dipelajari pada suasana serta keadaan nyata ataupun bisa memakai hokum- hukum, rumus, meode dalam suasana nyata.

4. Analisis, ialah kemampan buat menguraikan objek kedalam bagian- bagian lebih kecil, namun maih didalam sesuatu struktur objek tersebut serta masih terpaut satu sama lain. Dimensi keahlian merupakan dia bisa menggambarkan, membuat bagan, membedakan, dan memisahkan.

5. Sintetis, ialah sesuatu keahlian buat mengubungkan bagian- bagian didalam sesuatu wujud totalitas yang baru ataupun keahlian buat menyusun perumusan bau dari formulasi- formulasi yang terdapat. Seorang yang dikira mempunyai keahlian merupakan kala dia bisa menyusun, meringkaskan, merancang, serta membiasakan sesuatu teori ataupun rumusan yang telah terdapat.

6. Penilaian, ialah keahlian buat melaksanakan evaluasi terhadap sesuatu objek. Penilaian bisa memakai kriteria yang sudah terdapat ataupun disususn sendiri.

Bagi Listiani(Sukesih \& Dkk., 2020) pengetahuan merupakan hasil pengindraan manusia, dengan kata lain pengetahuan didapatkan lewat indra yang dipunyai oleh seorang ataupun hasil tau seorang terhadap sesuatu objek lewat indra yang dimilikinya tersebut. Penginderaan bisa terjalin dari panca 
indera manusia ialah, indera rungu, pengelihatan, penciuman, serta peraba.

Dimana sebagian dari pengetahuan diperoleh lewat mata serta kuping. Tiap orang mempunyai pengetahuan, serta tiap orang hendak mempunyai tingkatan pengetahuan yang berbeda- beda. Bagi Listiani(Sukesih \& Dkk., 2020) tingkatan pengetahuan manusia secara garis besar ialah: Ketahui(Know), Menguasai(Comprehensif),Aplikasi(Aplicatio n), Analisis(Analysis), Sintesis(Synthesis), serta Penilaian(Evaluation).

Jadi bisa disimpulkan kalau pengetahuan ialah hasil dari ketahui sehabis menusia ataupun orang melaksanakan penginderaan terhadap sesuatu objek. Pengetahuan sebagian besar diporeleh lewat indera penglihatan serta rungu. Pengetahuan pula bisa diperoleh lewat pembelajaran, pengalaman diri sendiri serta pengalaman orang lain.

Banyak metode yang bisa dicoba buat mendapatkan sesuatu pengetahuan, salah satu triknya merupakan dengan aktivitas belajar. Belajar ialah sesuatu wujud aktivitas yang bisa mencerdasakan, dimana lewat proses belajar bisa membuat seorang mendapatkan pengetahuan baru dan bisa menaikkan pengetahuan. Banyak sekali akibat yang bisa dialami untuk seorang yang mempunyai pengetahuan yang luas salah satunya merupakan dalam pergantian sikap(Sukesih \& Dkk., 2020).

Bagi (Azwar, 2003), ada berbagai aspek yang dapat mempengaruhi yaitu:
a. Umur
b. Jenis Kelamin
c. Pendidikan
d. Lama Kerja

Menurut Budiman dkk (Retnaningsih. \& Ragil, 2016), faktor- faktor yang dapat mempengaruhi pengetahuan adalah sebagai berikut:

a. Pendidikan

Pendidikan merupakan pengetahuan yang sangat erat kaitan nya dengan pembelajaran besar diharapkan, orang tersebut hendak terus menjadi luas pula pengetahuannya. Tetapi butuh ditekankan kalau seorang yang memiliki pendidikan yang rendah bukan bearti memiliki pengetahuan yang rendh pula.

b. Data ataupun media massa

Data didapatkan baik dalam pembelajaran yang resmi maupun yang tidak resmi atau nonformal yang memberikan pengaruh jangka pendek sehingga menciptakan sesuatu pengetahuan.

c. Sosial, budaya serta ekonomi

Kerutinan dan tradisi yang dicoba orangorang lewat penalaran apakah yang dicoba baik ataupun kurang baik. Tidak hanya itu status ekonomi seorang pula memastikan tersedianya sesuatu sarana buat aktivitas tertentu sehingga status sosial ekonomi seorang pengaruhi pengetahuannya.

d. Lingkungan

Lingkungan merupakan seluruh perihal yang terdapat disekitar manusia, baik area raga, biologis, ataupun sosial. Area bisa mempengaruhi terhadap proses masuknya pegetahuan ke dalam orang yang berda pada area tersebut.

e. Pengalaman

Pengalaman dari proses belajar dalam bekerja yang dibesarkan bisa membagikan pengetahuan serta keahlian handal, dan pengalaman belajar sepanjang bekerja 
yang bisa meningkatkan keahlian dalam mengambil suatu keputusan.

\section{f. Usia}

Usia sanggup mengendalikan energi tangkap serta pola pikir seorang. Sebab terus menjadi bertambahnya umur hingga terus menjadi tumbuh pula energi tangkap serta pola pikirnya sehingga pengetahuan yang diperoleh terus menjadi banyak.

\section{Self-Regulation}

Self Regulated Learning pada pembelajaran ialah sebuah proses mahasiswa dalam mengaktifkan pikiran, perasaan, maupun tindakan untuk mencapai keberhasilan dalam belajar. Schunk dan Zimmerman (Hidayah \& Atmok o, 2014) menyatakan bahwa siswa dapat dikatakan sebagai self regulated learning jika pada proses belajar dapat turut aktif baik secara kognisi, motivasional, serta tindakan (behavior). artinya siswa memulai belajar dengan sendiri agar memperoleh pengetahuan dan keterampilan yang diinginkan tanpa terpacu oleh guru, orangtua maupun orang lain.

Menurut (Ghufron, 2012), selfregulation atau pengelolaan diri merupakan cara individu guna mengatur diri sendiri dalam suatu kegiatan dengan melibatkan kemampuan metakognisi, motivasi dan perilaku aktif (Ghufron, 2012). Menurut Self-Regulation diartikan juga sebagai prosesnya dimana mahasiswa memelihara dan mengaktifkan kognisi, perilaku dan dapat mempengaruhi pencapaian dan tujuan secara sistematis.
Menurut Schunk \& Zimmerman (Hidayah \& Atmok o, 2014) terdapat beberapa karakteristik dari self regulated learning yaitu sebagai berikut:

1. Menetapkan tujuan yang khusus untuk individu itu sendiri.

2. Beradaptasi dengan strategi yang cocok demi mencapai tujuan.

3. Kinerja ditinjau dengan selektif.

4. Menyesuaikan kondisi fisik dan lingkup sosial agar sesuai dengan tujuan.

5. Mengatur dan menggunakan waktu dengan efisien.

6. Melakukan evaluasi diri mengenai cara yang diterapkan.

Dalam teoritis kogntif sosial, regulasi diri dipaparkan selaku perihal spesial pada suasana tertentu, ialah pembelajar tidak diharapkan mempunyai regulasi diri yang balance pada seluruh domain. Bagi Bandura, keberfungsian manusia mencakup interaksi resiprokal antara sikap, variabel area, dan kognisi serta aspek personal yang lain. Teori kognitif sosial mempunyai 3 pemikiran ataupun anggapan terhadap SRL(Kristiyani, 2016), ialah:

1. Triadic Reciprocality,

Teori kognitif sosial memandang terdapatnya akibat timbal balik dari 3 aspek yang pengaruhi SRL siswa,ialah aspek personal, area, serta sikap. Bagi teori ini, SRL tidak cuma didetetapkan oleh aspek dalam diri siswa, namun dipengaruhi oleh aspek ingkungan serta sikap yang terjalin secara timbal balik.

2. Self- efficacy,

Teori kognitif sosial memandang kalau efikasi diri ialah salah satu variabel utama yang pengaruhi SRL siswa. pemikiran terhadap efikasi diri siswa bisa teruji dengan 2 
aspek berarti dalam SRL, ialah strategi belajar serta monitoring diri. maksudnya siswa yang mempunyai efikasi diri besar mempunyai kemampuan baik dalam strategi belajar serta monitor hasil belajarnya.

3. Subprocesses in self- regulation,

Teori kognitif sosial berpikiran kalau regulasi diri dibagi dari 3 sub proses, ialah: observasi diri, evaluasi diri, serta respon diri yang silih berhubungan satu sama lain.

Regulated Learning termasuk ke dalam Model Taxonomy Pintrich. Dimana berfokus dengan fase serta zona regulasi diri. Bagi model ini fase regulasi diri meliputi: 1) Fase identifikasi serta perencanaan belajar, 2) Fase monitoring serta kontrol strategi pendidikan, serta 3) Fase respon serta refleksi. Pada area regulasi diri tersebut bisa dipecah lagi ke dalam 4 jenis besar, ialah kognisi, motivasi, sikap, serta konteks. Pada perspektif ini model Self Regulated Learning dicirikan dengan 4 anggapan universal. 2 anggapan awal dilandaskan selaku isi, sebaliknya anggapan 3 serta 4 dilandaskan suatu proses. Ke- empat anggapan tersebut merupakan:

Awal, mahasiswa merupakan partisipan aktif pada proses belajar. karena, tidak terdapat proses belajar yang terjalin tanpa pengaruh ciri pembelajar, serta tidak terdapat area yang bisa' membuat' seluruh orang belajar; Kedua, tiap mahasiswa memiliki keahlian, paling tidak kemampuan, dalam memonitor, mengendalikan, serta meregulasi kognisi, motivasi, serta perilakunya. Mahasiswa bisa pengaruhi, area di mana dia belajar; Ketiga, mahasiswa bisa mentargetkan standar ataupun tujuan belajar dengan maksimal, dikala menyadari tujuan tersebut, mahasiswa bisa memonitor perkembangannya serta meregulasi kognisi, motivasi, serta perilakunya; serta Keempat, area belajar, ciri individual, serta tujuan mahasiswa berhubungan secara dinamis(Kristiyani, 2016).

\section{METODE PENELITIAN}

\section{Jenis Penelitian}

Riset ini memakai pendekatan kuantitatif dengan memakai tata cara survei. Riset ini diucap tipe riset korelatif, sebab hendak mendapatkan data sejauhmana korelasi antara self- regulation dengan pengetahuan pada mahasiswa fakultas psikologi UIN RF.

\section{Variabel Penelitian}

Variabel X( leluasa) dalam riset ini merupakan pengetahuan sebaliknya variabel Y( terikat) dalam riset ini merupakan selfregulation memakai kuesioner yang dirancang oleh periset bersumber pada aspek- aspek pengetahuan dari Notoadmodjo(Sunaryo, 2004) serta aspek- aspek self- regulation bagi Zimmerman serta Pons(Ghufron, 2012). Metode analisis informasi yang digunakan dalam riset ini merupakan korelasi product moment dari Spearman.

\section{Subjek Penelitian}

Populasi dari riset ini merupakan mahasiswa fakultas psikologi UIN RF semester 6. Ilustrasi dalam riset ini mahasiswa fakultas psikologi yang lagi mengampuh mata kuliah PARK( Pertumbuhan Anak serta Anak muda Berkebutuhan Spesial). Dimana ilustrasi pada riset ini berjumlah 30 mahasiswa.

\section{Metode Pengumpulan Data}

Metode pengumpulan informasi yang digunakan dalam riset ini merupakan kuesioner yang berisikan sebagian persoalan terpaut self- regulation serta pengetahuan. Responden hendak dimohon menanggapi tiap persoalan yang terdapat pada kuesioner riset tersebut tanpa terkecuali. Kuesioner riset 
tersebut didistribusikan secara langsung oleh periset.

\section{Metode Analisis Data}

Metode analisis informasi yang digunakan dalam riset ini merupakan memakai statistik deskriptif buat memandang tingkatan self- regulation serta pengetahuan mahasiswa fakultas psikologi. Tidak hanya itu, metode analisis informasi yang digunakan merupakan uji korelasi product moment dari Spearman buat memandang korelasi antara selfregulation serta pengetahuan baik buat tiaptiap mahasiswa fakultas psikologi yang jadi subjek riset. Analisis informasinya memakai dorongan SPSS tipe 16.

\section{HASIL DAN PEMBAHASAN}

Riset ini memakai try out terpakai. Proses pengambilan informasi dicoba pada 20- 23 Juni 2021 dengan memberikan kuesioner kepada 30 mahasiswa fakultas psikologi UIN RF baik pria ataupun wanita. Di dalam kuesioner tersebut, periset memberikan 2 skala ialah skala pengetahuan serta skala selfregulation. Skala pengetahuan terdiri dari 30 aitem persoalan serta skala self- regulation sebanyak 55 aitem.

\section{Pengujian Kuesioner}

Pengolahan informasi terhadap kuesioner dicoba dengan memakai uji validitas, uji reliabilitas, serta uji kecukupan informasi yang dihitung dari hasil penyebaran kuesioner terhadap beberapa responden.

\section{Uji Validitas}

Buat medapatkan informasi yang akurat serta objektif, dibutuhkan kecermatan tertentu butuh dicoba uji validitas. Validitas merupakan ketepatan serta kecermatan skala dalam melaksanakan guna ukurnya, maksudnya validitas merupakan seberapa akurat sesuatu perlengkapan ukur bisa menciptakan informasi cocok dengan tujuan ukurnya(Azwar, 2005). Validitas dalam pengukuran ini merupakan validitas isi yang bisa diestimasi dari proses pengujian lewat professional judgement. Bersumber pada Insrumen yang digunakan dalam riset ini hingga Validitas yang digunakan dalam riset ini merupakan validitas konstruk.

\section{Uji Reliabilitas}

Sehabis melaksanakan uji validitas hingga langkah berikutnya merupakan melaksanakan uji reliabilitas. Reliabilitas perlengkapan ukur mengacu pada konsistensi ataupun keyakinan hasil ukur, yang memiliki arti kecermatan pengukuran. Apabila terus menjadi besar koefisien reliabilitas( mendekati angka 1.00), hingga semakin besar reliabilitasnya(Azwar, 2006). Uji reliabilitas skala pengetahuan serta self- regulation. Norma dihitung dengan metode statistik rumus Alpha Cronbach.

Tabel 1

Interpretasi reliabilitas

\begin{tabular}{|c|c|}
\hline Besar linear $\mathbf{r}$ & Interpretasi \\
\hline (Antara) $0,800-1,00$ & Tinggi \\
\hline $0,600-0,800$ & Cukup \\
\hline $0,400-0,600$ & Agak Rendah \\
\hline $0,200-0,400$ & Rendah \\
\hline $0,000-0,0,200$ & Sangat Rendah \\
\hline
\end{tabular}

Tabel 2

Skala Instrumen Pengetahuan

\begin{tabular}{|c|c|}
\hline Skala & Makna \\
\hline 1 & Sangat setuju \\
\hline 2 & Setuju \\
\hline 3 & Tidak setuju \\
\hline 4 & Sangat tidak setuju \\
\hline
\end{tabular}


Tabel 3

Reliabilitas Instumen Pengetahuan Reliability Statistics

\begin{tabular}{|r|r|}
\hline \multicolumn{1}{|c|}{ Cronbach's Alpha } & N of Items \\
\hline .847 & 30 \\
\hline
\end{tabular}

Dari hasil uji coba dspt dilihat bahwa 23 item dinyatakan valid dari 30 item dan didapatkan reliabilitas instrumen pengetahuan sebesar 0,847 . Artinya, reliabilitas instrumen tergolong sangat tinggi.

Tabel 4

Skala Instrumen Self-Regulation

\begin{tabular}{|c|c|}
\hline Skala & Makna \\
\hline $\mathbf{1}$ & Sangat sesuai \\
\hline $\mathbf{2}$ & Sesuai \\
\hline $\mathbf{3}$ & Tidak sesuai \\
\hline 4 & Sangat tidak sesuai \\
\hline
\end{tabular}

Tabel 5

Reliabilitas Instrumen Self-Regulation

Reliability Statistics

\begin{tabular}{|r|r|}
\hline \multicolumn{1}{|c|}{ Cronbach's Alpha } & N of Items \\
\hline .928 & 55 \\
\hline
\end{tabular}

Dari hasil yang telah dilakukan dapat dilihat bahwa 53 item dinyatakan valid dari 55 item dan didapatkan reliabilitas instrument self-regulation sebesar 0,928. Artinya, reliabilitas instrument tergolong sangat tinggi.

\section{Uji Normalitas}

Setelah uji validitas dan reliabilitas dilakukan, analisis data variabel penelitian ini terdistribusi normal (sig.(p) $>0.05)$. Perhitungan uji normalitas data dilakukan dengan uji Kolmogorov-Smirnov dengan menggunakan uji statistika.

Tabel 6

\section{Uji Normalitas}

One-Sample Kolmogorov-Smirnov Test

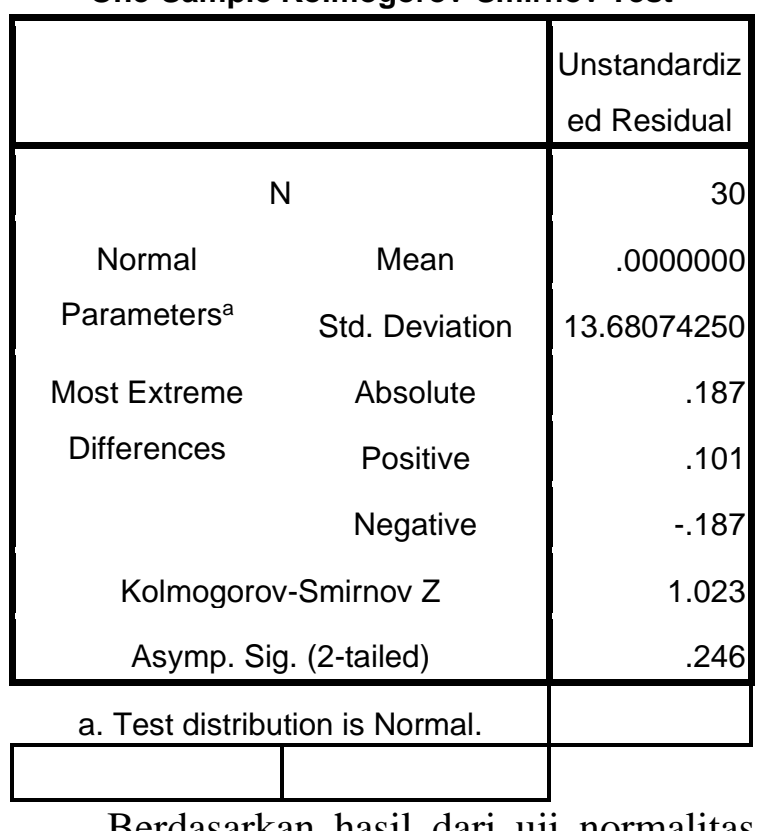
yang telah diketahui bahwa nialai signifikan 0 , $246>0.05$ maka dapat disimpulkan bahwa nilai residual berdistribusi normal.

\section{Uji Korelasional}

Dari hasil perhitungan korelasi Pearson, diperoleh koefisien antara pengetahuan dengan self-regulation sebesar positif 0,505 dengan taraf signifikansi sebesar $\mathrm{p}=0,004$.

Tabel 7

Uji Korelasional 


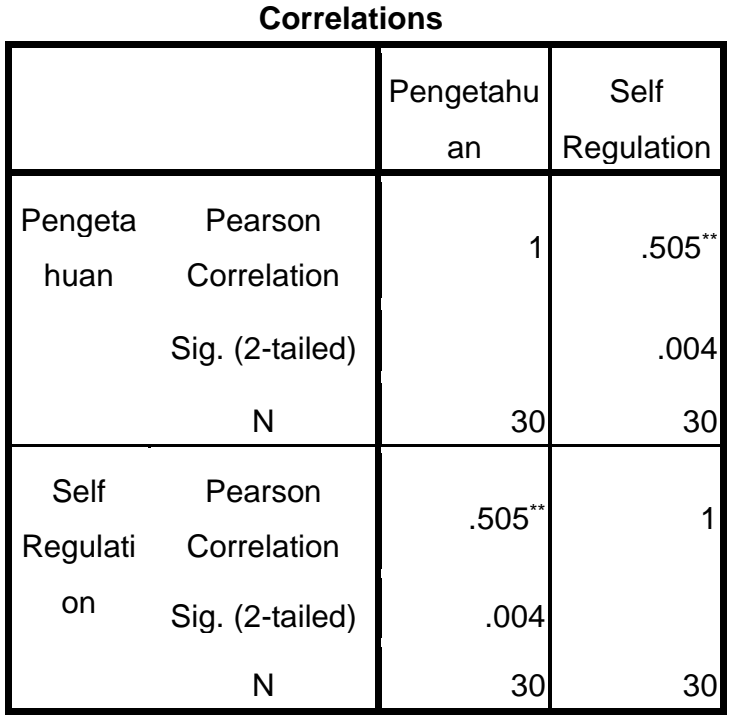

**. Correlation is significant at the 0.01 level (2tailed).

Berdasarkan dari hasil data dapat disimpulkan bahwa variabel $\mathrm{X}$ dengan $\mathrm{Y}$ memiliki korelasi dengan derajat hubungan yaitu korelasinya sedang dan bentuk hubungannya ialah positif. Maksud bentuk hubungan yang positif adalah semakin tinggi pengetahuan maka semakin tinggi pula selfregulationnya atau semakin rendah pengetahuan maka semakin rendah pula selfregulationnya.

\section{SIMPULAN}

Bersumber pada ulasan tadinya, kesimpulan yang bisa diambil merupakan terdapat ikatan positif antara self- regulation dengan pengetahuan menimpa analisis pertumbuhan sosial pada mahasiswa fakultas psikologi UINRF. Perihal ini bersumber dari hasil uji normalitas dikenal nilai signifikansi 0 , 246

0. 05 hingga bisa disimpulkan kalau nilai residual berdistribusi wajar serta hasil perhitungan korelasi Pearson, diperoleh koefisien antara pengetahuan dengan selfregulation sebesar positif 0,505 dengan taraf signifikansi sebesar $\mathrm{p}=0,004$.

Dengan terdapatnya riset ini diharapkan orang spesialnya mahasiswa fakultas psikologi bisa tingkatkan serta mempertahankan uraian dan pengetahuan menimpa analisis pertumbuhan sosial PARK dengan mempunyai selfregulation ataupun pengelolaan diri yang baik. Untuk periset yang mau mengangkut judul yang sama diharapkan bisa mempelajari lebih baik lagi menimpa self- regulation serta pengetahuan, spesialnya pada aspek yang pengaruhi kedua variabel tersebut serta memakai lebih banyak lagi ilustrasi riset nya. Periset pula berharap riset berikutnya bisa lebih dibesarkan serta dihubungkan dengan variabel psikologis yang lain, sehingga riset menimpa self- regulation serta pengetahuan bisa tumbuh serta membagikan khasiat buat mahasiswa.

\section{DAFTAR PUSTAKA}

Azwar, S. (2003). Sikap Manusia: Teori dan pengukurannya. Pustaka Pelajar.

Azwar, S. (2005). Metode Penelitian. Pustaka Belajar Offset.

Azwar, S. (2006). Reliabilitas dan Validitas. Pustaka Pelajar.

Gafur, H. (2015). Mahasiswa dan Dinamika Dunia Kampus. CV. Rasi Terbit.

Ghufron, M. N. (2012). Teori-Teori Psikologi. Ar-Ruzz Media.

Helmi, A. F., \& Arisudana, M. (2009). Kepemimpinan Transformasional, Kepercayaan dan Berbagi Pengetahuan Dalam Organisasi. Jurnal Psikologi, 36, 95-105.

Hidayah, N., \& Atmok o, A. (2014). Landasan

Sosial Budaya dan Psikologis

Pendidikan: Terapannya di kelas. Gunung Samudera. 
Kristiyani, T. (2016). Self-Regulated Learning. Konsep, Implikasi, dan tantangannya bagi siswa di Indonesia. Sanata Dharma University Press.

Notoatmodjo, \& Soekidjo. (2003). Pengembangan Sumber Daya Manusia. PT. Rineka Cipta.

Rajaratenam, S. G., Martini, R. S., \& Lipoeto, N. I. (2014). Hubungan Tingkat Pengetahuan dan Sikap dengan Tindakan Pencegahan Osteoporosis Pada Wanita Usila di Kelurahan Jati. Jurnal Kesehatan Andalas, 2.

Retnaningsih., \& Ragil. (2016). Hubungan Pengetahuan Dan Sikap Tentang Alat Pelindung Telinga Dengan Penggunaanya Pada Pekerja di PT X.
Jurnal Of Industrial Hygiene and Occuoational Health., 1.

Saadah, N., Suparji., \& Sulikaj. (2020). Stimulasi Perkembangan Ibu melalui Bermain dan Rekreasi Pada Anak Usia Dini. Scopindo Media Pustaka.

Sukesih, \& Dkk. (2020). Pengetahuan Sikap Mahasiswa Kesehatan Tentang Pencegahan Covid-19 Di Indonesia. Jurnal Ilmu Keperawatan Dan Kebidanan., 11.

Sunaryo. (2004). Psikologi Untuk Keperawatan. EGC.

Zimmerman, B. . (1989). A Social Cognitive View of Self-Regulated Academic Learning. Journal of Educational Psychology, 81, 2-23. 